\title{
IL23A wt Allele
}

National Cancer Institute

\section{Source}

National Cancer Institute. IL23A wt Allele. NCI Thesaurus. Code C61151.

Human IL23A wild-type allele is located in the vicinity of $12 q 13.2$ and is approximately 2 $\mathrm{kb}$ in length. This allele, which encodes interleukin-23 subunit alpha protein, which is involved in the transcriptional activation of STAT4, the stimulation of cytokine production and immune responses. It has been asserted that certain tumors promote inflammation via IL23A to induce angiogenesis. 